216 川崎市の二瑄用水におけるBOD值の変化とChironosus yoshiratsui の発生変趿 (1986〜1994)

传藤英媇（川崎市御生研究所）

Population dynamics of Chironosus yoshieatsui in relation to $B O D$ of an irrigation ditch in Kawasaki

Sato $H$.

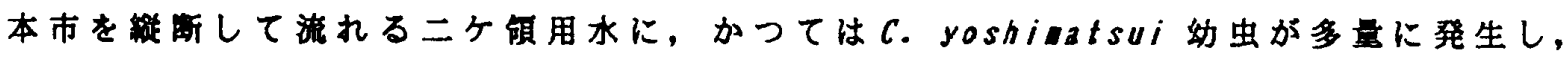

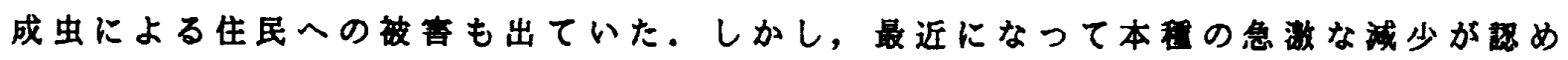
られた。これは，本市の二ヶ領用水净化事業によってBOD俌が低下したためである。す なわち, BOD值が $10 \mathrm{mg} / \mathrm{l}$ 以下になつたとき, ユスリカ幼虫は底泥 $100 \mathrm{~cm}$ 当たり 1,000 個体 以下になり，1定点当たりのライトトラップに捕獾される成虫数は10個体以下になった。 その結果，住民からの苦情・相件数も著しくしく瑊少した。ここでは，これらの関 係が明礶に示された。本市における河川の浄化事業は更に通められているために，こ の川からユスリカが, 従前のように多量に発生することは考えられない状況である。

\title{
217 名古展市の沉水眝木池におけるュスリカ䣩查
}

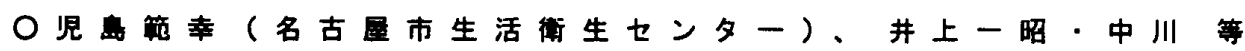
(名古星市南保健所)

A survey of chironomid nidges in a brackish tiaberpond of Nagoya City.

Kojiga N., Inoue K. and Nakagawa H.

今回、畹木池に隣接するゴルフ場紼習埸からのユスリカの苦情があり、1995年 2 月から 1 年にわたり名古屋市南区の貯木池てュスリカ睛查を实施した。この眝木池

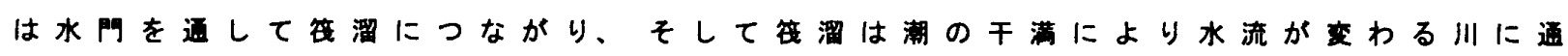

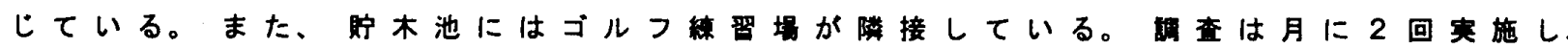

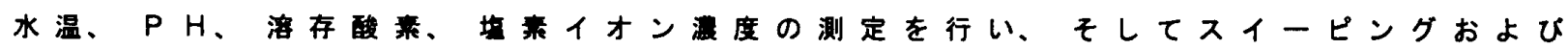
ライトトラップによる成虫の捕集と测定点付近の泥のすくい取りによる幼䗎探を 行つた。B○Dについては月に 1 回测定した。今回の查ではスイーピングたい てシオユスリカChirononus salinariusが5月10日～11月28日に捕集され、特に5月 25日と6月23日に多く捕集された。次にイノウエュスリカDicrotendipes inoueiが 5月25日と6月23日に多く捕集された。ライトトラップにおいて C.salinariusが3月 10日〜11月28日に捕集され、5月25日〜6月23日に多く捕集さた。また、D.inoueiは 6月23日〜7月25日、9月13日と9月26日に捕集され、6月23日〜 7月25日に多く捕集さ れた。 